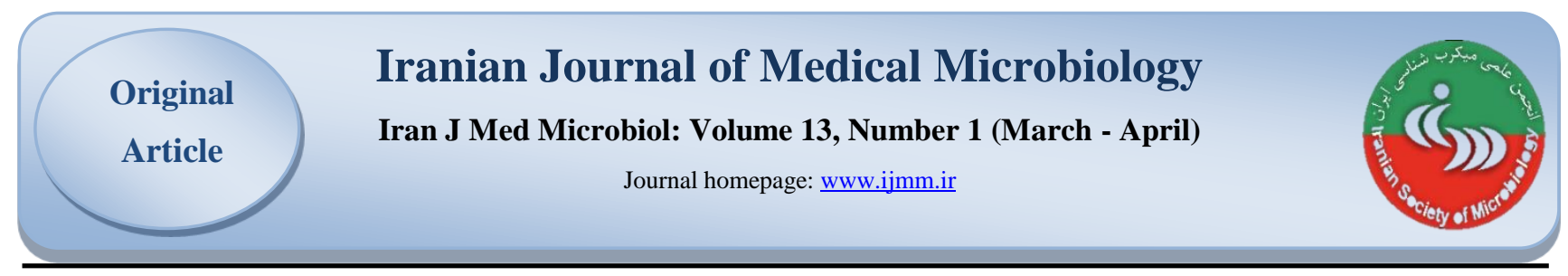

\title{
Investigation of Mutations of ERG11 Gene in Fluconazole Resistant Strains of Candida Albicans Isolated From Patients With Volvovaginitis in West of Mazandaran
}

\author{
Masoumeh Majdi', Zeinab Khazaei Koohpar ${ }^{1 *}$, Ayatollah Nasrollahi Omran²
}

1. Department of Cell and Molecular Biology, Faculty of Biological Sciences, Tonekabon Branch, Islamic Azad University, Tonekabon, Iran

2. Department of Medical Mycology, Tonekabon Branch, Islamic Azad University, Tonekabon, Iran

\section{Article Information}

\section{Article Subject:}

Molecular Microbiology

DOI: $10.30699 / \mathrm{ijmm} .13 .1 .14$

Corresponding author:

\section{Zeinab Khazaei Koohpar,}

Department of Cell and

Molecular Biology, Faculty of

Biological Sciences, Tonekabon

Branch, Islamic Azad University,

Tonekabon, Iran

Email:

khazaei@toniau.ac.ir

Use your device to scan and read the article online

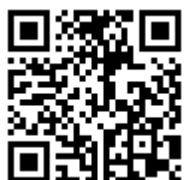

\section{Abstract}

Background and Aims: Candida albicans as an opportunistic fungal pathogen in human is the cause of volvovaginitis candidiasis. Azole resistance is cinsiderable as worldwide problem in treatment of candidiasis. Azole resistance can occur through different mechanisms such as mutation in ERG11 gene. The aim of our study was evaluation of ERG11 gene mutations in fluconazole resistant islotes of $C$. albicans obtained from patients with volvovaginitis in west of Mazandaran.

Materials and Methods: In this study, clinical specimens were obtained from vaginal mucosa of 120 individual. C. albicans isolates were identified by standard methods such as germ tubes and culture in chrome agar media. Susceptibility test to fluconazole in the isolates was evaluated by Disc diffusion and MIC methods. After DNA extraction, ERG11 gene mutations in clinical isolates were determined by PCRsequencing method.

Results: From 45 isolates of C. albicans, 40 isolates were resistant to fluconazole. The MIC of fluconazole in isolates was determined between 2 to $64 \mu \mathrm{g} / \mathrm{ml}$. Also, sequencing analysis showed that 7 fluconazole resistant isolates had three missense mutations (D116E, K128T and A114S) in ERG11 gene.

Conclusion: It apears that high frequency of floconazol resistance is the results of different reasons such as mutations in ERG11 gene in C. albicans isolates.

Keywords: Candida albicans, ERG11, Fluconazole, MIC, Mutation 


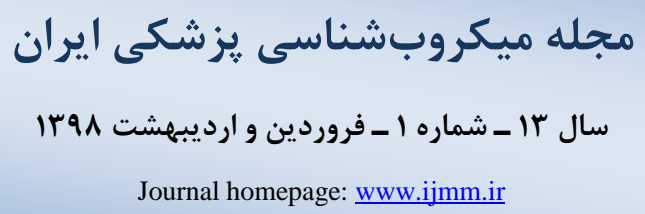

\section{بررسى جهشهاى زن ERG11 در سويههاى كانديدا آلبيكنس مقاوم به فلوكونازول جداشده از افراد مبتلا به ولووازينيت در غرب مازندران}

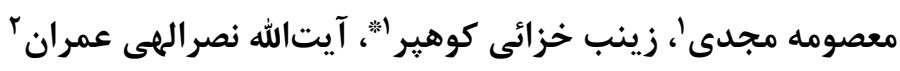

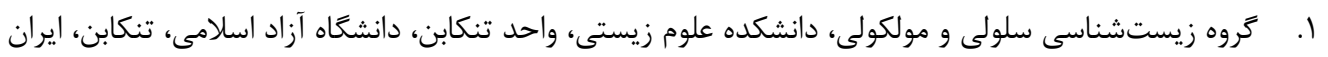

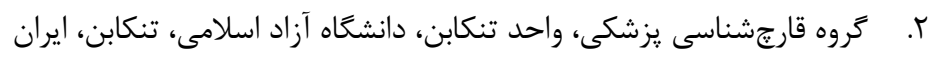

\section{جكيله}

زمينه و هدف: كانديدا آلبيكنس نوعى پاتورن قارجى فرصتطلب در انسان است كه باعث ولووارثنيت كانديديايى مىشود.

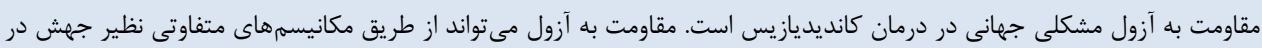

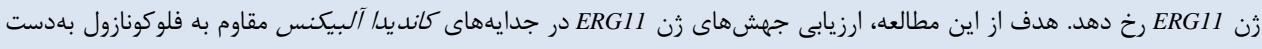

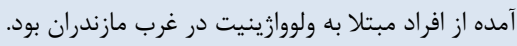

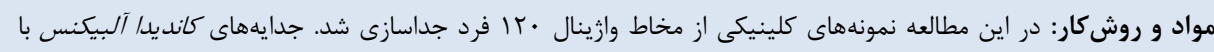

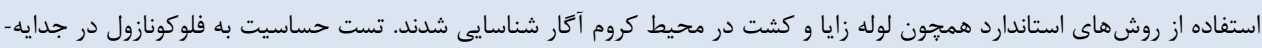

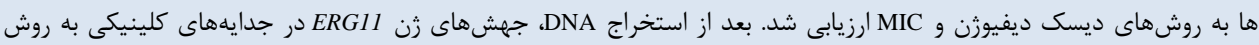
PCR

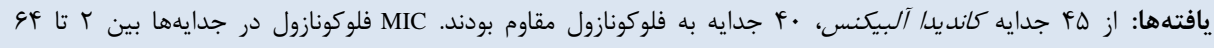

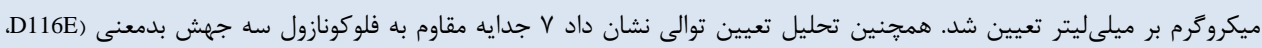
(A114S ،K128T در زن ERG11 داشتند. نتيجه كيرى: به نظر مى رسد فر كانس بالاى مقاومت به فلوكونازول در اين مطالعه نتيجه عوامل مختلفى از جمله وقوع جهش در زن ERG11 در جدايههاى كانديدا آلبيكنس باشد.

كلمات كليدى: كانديدا آلبيكنس، ERG11، فلوكونازول، MIC، جهش

اطلاعات مقاله

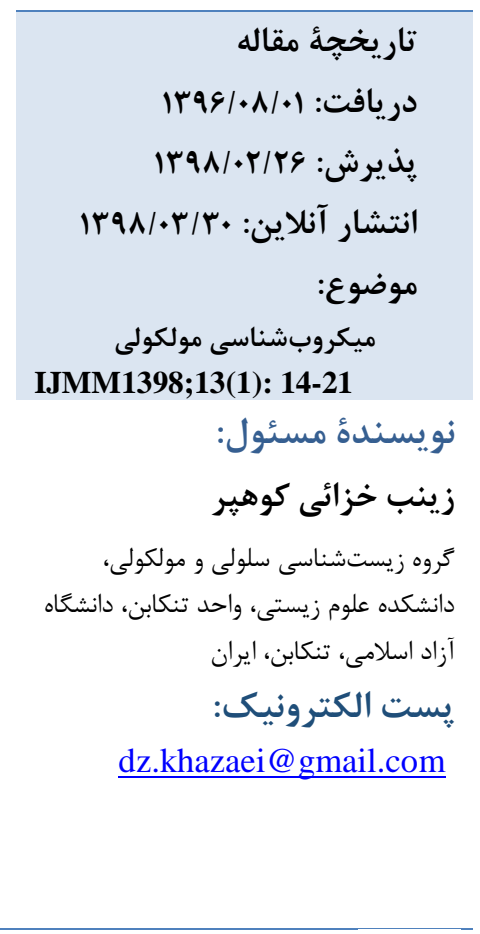

مقدمه

داروهاى سركوبگر ايمنى، فراوانى و شدت اين عفونتها افزايش جشمخيرى داشته است (F). برخى تركيبات دارويى ضدقارج

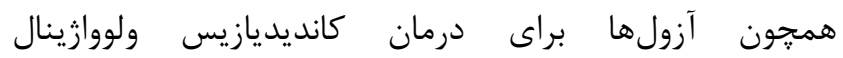
(vulvovaginal Candidiasis) نظير فلوكونازول، ايتراكونازول و وريكونازول با مهار سيتوكروم (Erg11p) P450 (ه). ارگوسترول يك تركيب ضرورى در غشاى يلاسمايى قارج

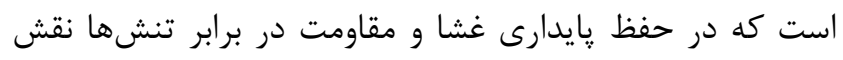

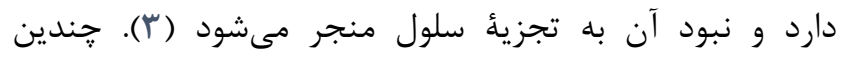
مكانيسم مقاومت به آزولها شناسايى شده كه شامل افزايش
كانديد/ آلبيكنس (Candida albicans) يكى از مهممترين مخمرهاى بيمارىزاى انسان و رايجترين گونهاى است كه در وازن •r تا • ه درصد از زنان سالم وجود دارد (ا، r). كانديدا يكى از فلورهاى قارجى طبيعى در انسان است كه مىتواند در سطوح مخاطى و ويوست كلونيزه شود و در شرايط خاص ميزبان از قبيل نقص سيستم ايمنى ناشى از سرطان، ييوند اعضا، عفونت HIV كانديديازيس، عفونتى است كه توسط كونه گهاى كانديدا به

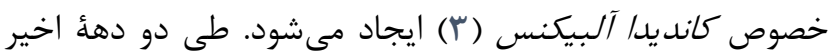
به دليل استفاده وسيع از آنتىبيوتيكها، استروئيدها و ساير 


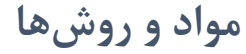 \\ جداسازى و كشت جدايههاى مخمر كانديدا آلبيكنس}

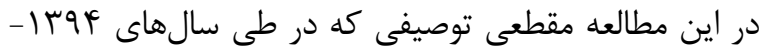

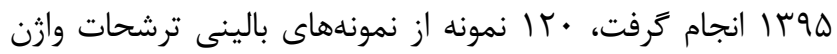

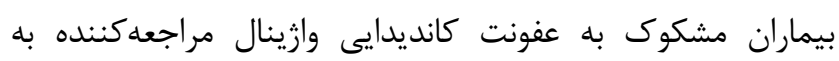

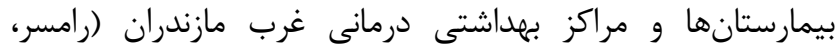

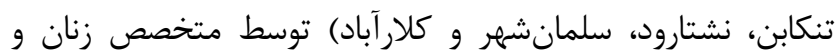

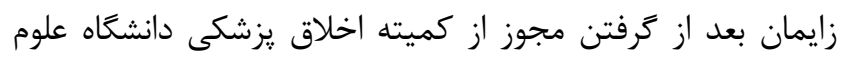
يزشكى (كد IR.GUMS.REC.1395.25) تهيه و تشخيص داده شد. نمونهها در لولههاى حاوى نرمال سالين (سرم فيزيولوزى) قرار

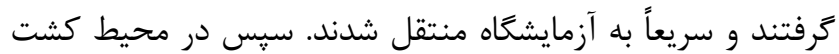

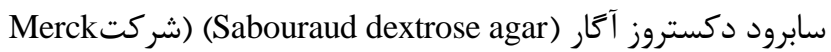

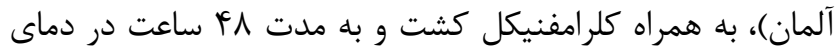
آل TV درجه سلسيوس انكوبه شدند. در ادامه، شناسايى كانديد

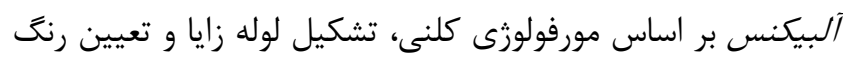
كلنىها در محيط كروم آتار كانديدا (شركت CHROMagar، فرانسه) انجام كرفت. از سويه (ATCC10231) PTCC 5027 به درعار عنوان سويه حساس و كنترل استفاده شد.

\section{سنجش حساسيت آنتىبيوتيكى}

به منظور تعيين الكَوى حساسيت دارويى، حساسيت يا

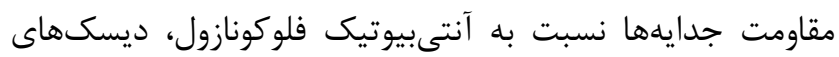

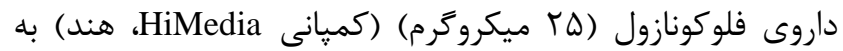

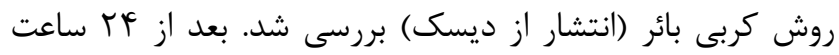

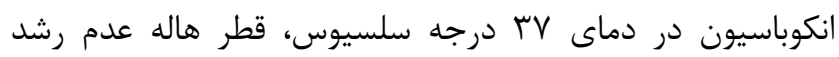
CLSI اطراف هر ديسك اندازهيرى و نتايج آن طبق استاندارد

2013 كزارش شد (جدول (1).

\section{تعيين MIC) Minimum Inhibitory Concentration}

براى تعيين حداقل غلظت بازدارندگى آنتىبيوتيك فلوكونازول، ابتدا جدايهها در محيط كشت سابورودكستروز براث

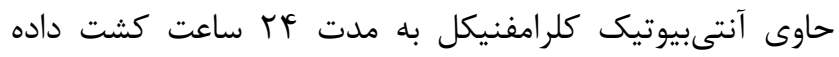
شدند. سيس رقتهاى متوالى آنتىبيوتيك فلوكونازول در محدوده

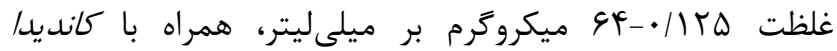

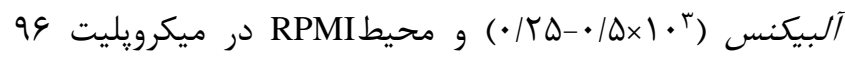

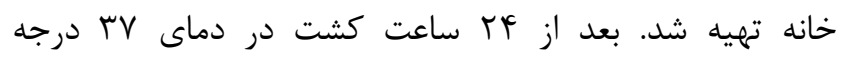
سلسيوس در انكوباتور شيكردار ميزان MIC بر اساس استاندارد

$$
\text { CLSI }
$$

بيان ERG11، كاهش تمايل Erg11p به آزول در اثر جهش در

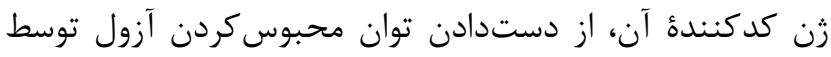

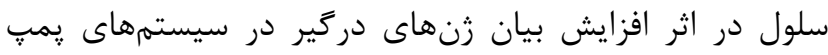

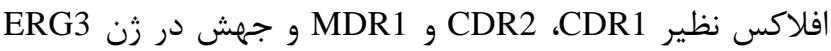

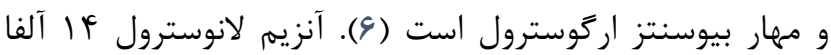
دمتيلاز آنزيمى مههم در سنتز اركوسترول است. اين آنزئن آنزيم مورد

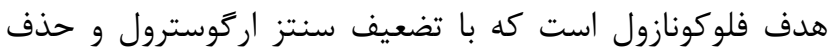

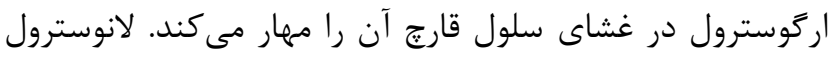

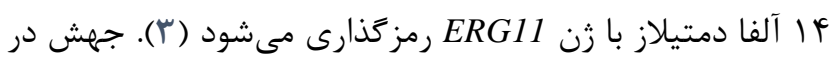

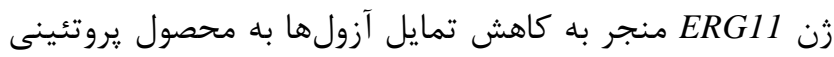
اين زن و درنتيجه ايجاد مقاومت به دارو در جدايههاى كانديدا

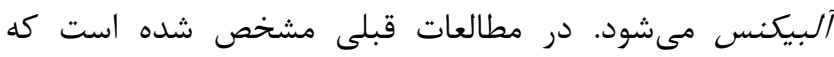

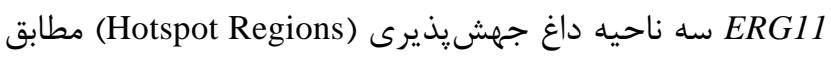

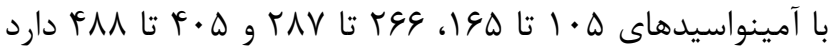

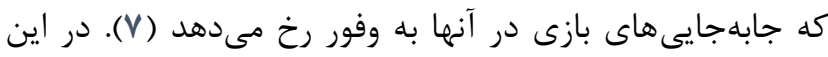

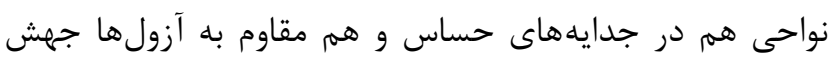
رخ مى دهد. مطالعات نشان داده است بين وقوع جهشهاى دراى خاص در بعضى نواحى و مقاومت به آزولها ارتباط وجود دارد (^)؛ به ديه

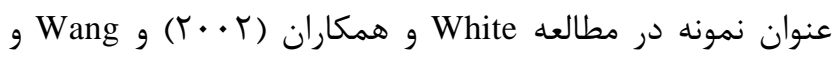

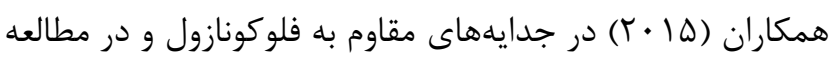

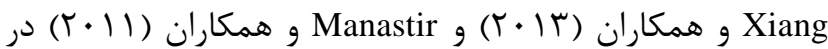

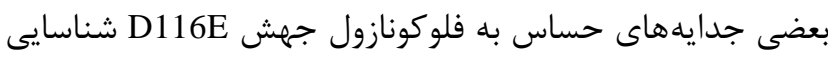

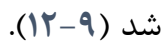

در مطالعات مختلف صدها جهش در اين زن شناسايى شده

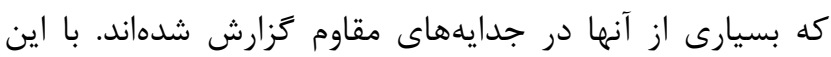

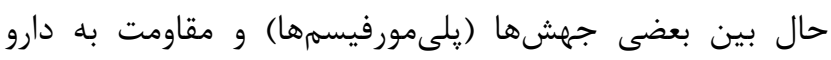

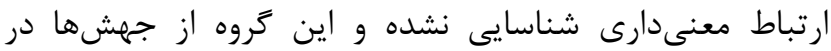
جدايههاى حساس نيز گزارش شده است. بنابراين لازم است در دراسئ

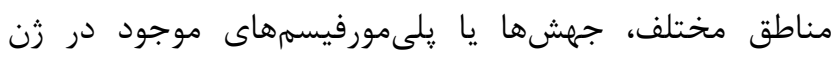
ERG11 در جدايههاى مقاوم و حساس بررسى شود و با مطالعات

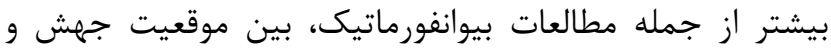

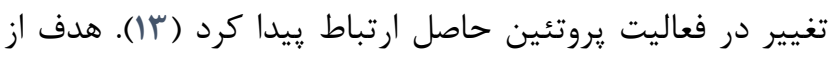

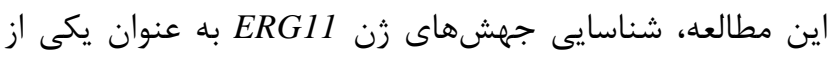
عوامل ايجادكننده مقاومت به فلوكونازول در جدايههاى كانديدا

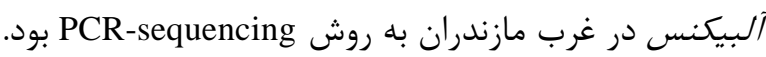




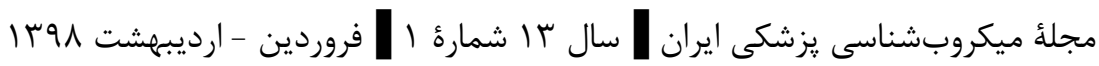

جدول ا. مقادير MIC و قطر هالؤ عدم رشد استاندارد براى جدايههاى كانديدا آلبيكنس بر اساس روش CLSI

\begin{tabular}{|c|c|c|c|c|c|c|c|}
\hline \multicolumn{3}{|c|}{ مقدار (gr/ml) MIC) } & \multicolumn{3}{|c|}{ قطر هاله (mm) } & \multirow{2}{*}{ غلظت آنتىبيوتيك در هر ديسك } & \multirow{2}{*}{ داروى ضدقارج } \\
\hline $\mathrm{R}$ & S-DD & S & $\mathrm{R}$ & S-DD & $S$ & & \\
\hline$\geq q 4$ & TIS-T & $\leq \Lambda$ & $\leq 1 f$ & $10-11$ & $19 \geq$ & $1 \cdot \mu \mathrm{gr}$ & فلوكونازول \\
\hline
\end{tabular}

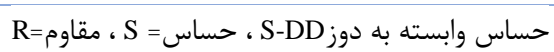

جدول r. (IF) PCR مشخصات جفت يرايمر استفادشده در واكنش

نام ير ايمر

ERG11-1F

ERG11-1R
توالى برايمر

5' - TTAGTGTTTTATTGGATTCCTTGGTT -3'

5'-TCTCATTTCATCACCAAATAAAGATC-3
PCR Pول محصول

483 bp
از نظر وجود جهش در نمونههاى مقاوم در مقايسه با نمونه (BLAST) استاندارد رفرنس موجود در سايت NCBI بررسى شد.

بافنه ها

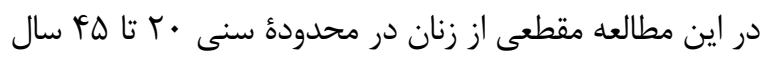

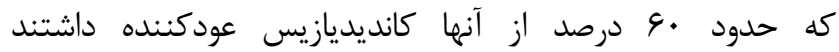
نمونه تحقيق، با تستهاى تشخيصى از جمله كشت در محيط كروم آكًار

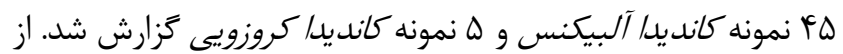
بين fD جدايه كانديدا آلبيكنس شناسايىشده، به روش انتشار از ديسك · · نمونه (9 1 درصد) مقاوم و له نمونه (1)

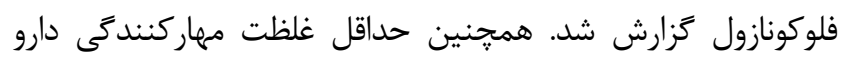
به روش براث دايلوشن براى نمونهای حساس و مقاوم تعيين (MIC)

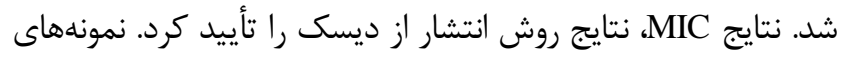

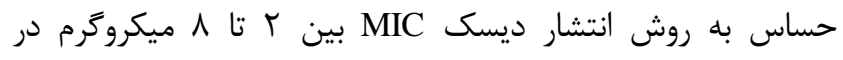
ميلىليتر و همةٔ جدايههاى مقاوم به MIC

داشتند.

جهشهاى زن ERG11 در جدايههاى مقاوم به فلوكونازول بعد از انجام واكنش PCR (شكل ())، بر اساس نتايج تعيينتوالى (جدول ץ) در 11 جدايه جهشهاى خاموش شناسايى شد. در

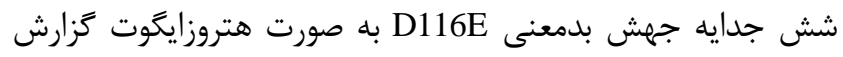
شد كه در كدون M-116، آسيارتيك اسيد به كلوتاميك اسيد تبديل شده بود (شكل (Y). همجنين در يك جدايه مقاوم جهش بدمعنى

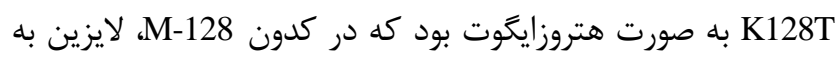

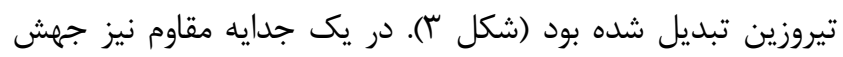

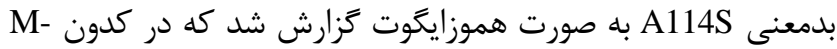
114، آلانين به سرين تبديل شده بود (شكل ؟ أ).

\section{تخليص DNA ت زمنومى}

جدايههاى كانديدا آلبيكنس در محيط سابورود دكستروز براث

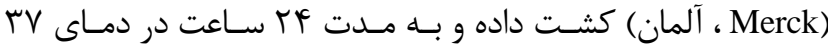

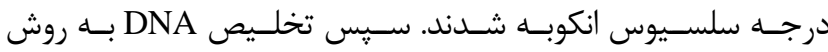

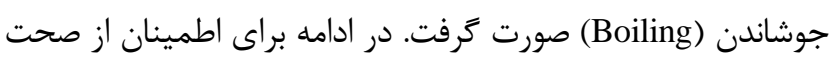
تخليص، نمونـهـهـاى DNA در زل آخـارز ه/ ال درصـد الكتروفـورز و

برسى شد.

\section{واكنش PCR و تعيين توالى زن ERG11}

بعد از تخليص DNA رنومى، اجزاى واكنش PCR با استفاده از كيت (AccuPower Pfu PCR PreMix شركت تكايوزيست) در حجم

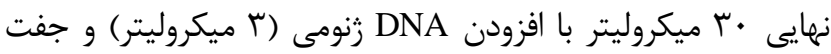

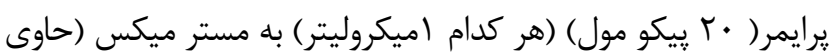
آنزيم، كوفاكتور و بافر مخصوص در حجم ه ميكروليتر) و ميكروليتر از آب ديونيزه آماده شد. شركت Bioneer (كره جنوبى) مينه سنتز يرايمرها (IF) را انجام داد (جدول ب). واكنش از ترموسايكلر (TUCH ، آمريكا) طبق برنامه زير انجام شد: يك

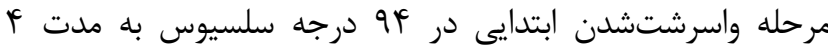
دقيقه، هr سيكل به ترتيب در دماى أq درجه سلسيوس به مدت لأ ثانيه، WT سلسيوس به مدت Y دقيقه و يك مرحله گسترش نهايى در دماى درجه سلسيوس به مدت • ا دقيقه.

بعد از اطمينان از تكىباند بودن محصولات PCR، نمونهها با حفظ زنجيره سرمايى توسط شركت تكايوزيست (ايران، تهران) به

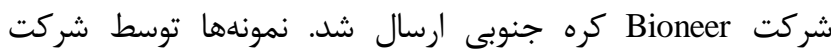
Bioneer نرمافزار CLC main workbench v3.5 و نرمافزار آنلاين بلاست 


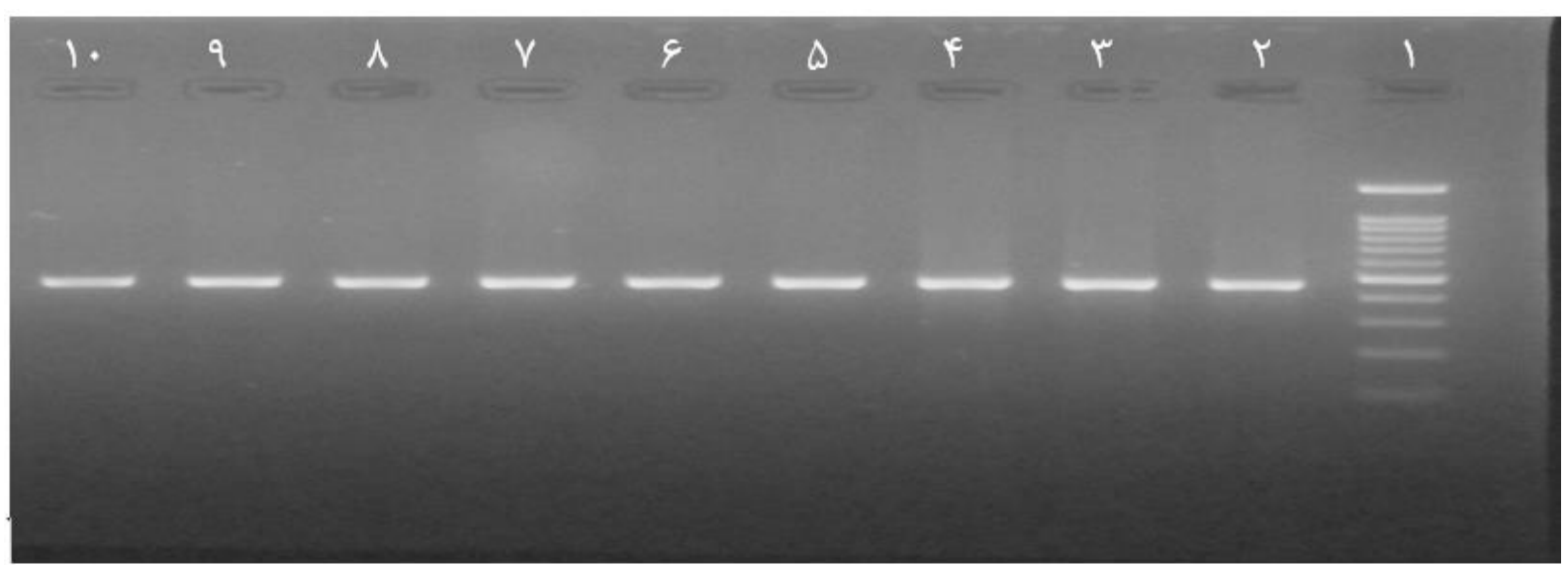

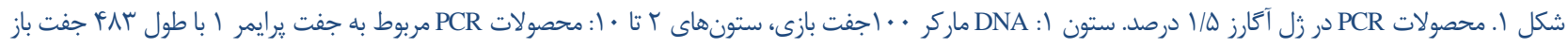

جدول r. تغييرات بازى و آمينواسيدى ايجادشده در رن ERG11 در جدايههاى كانديدا آلبيكنس مقاوم به فلوكونازول

\begin{tabular}{|c|c|c|}
\hline تغيير آمينواسيدى & تغيير بازى & تعداد جدايههاى داراى جهش (درصد) \\
\hline F72F & TTC(Phe) $>$ TTT(Phe $)$ & $(1 \Delta) 9$ \\
\hline F105F & TTT(Phe )>TTC(Phe) & $(F \Delta) \backslash \wedge$ \\
\hline A114S & GCT(Ala ) > TCT(Ser) & $(\Gamma / \Delta))$ \\
\hline D116E & GAT(Asp) $>$ GAA(Glu) & $(1 \Delta) 9$ \\
\hline K119K & AAA(Lys )>AAG(Lys) & $(1 \Delta)^{4}$ \\
\hline K128T & $\mathrm{AAA}($ Lys $)>\mathrm{ACA}(\mathrm{Thr})$ & $(Y / \Delta))$ \\
\hline S137S & $\mathrm{TCC}(\mathrm{Ser})>\mathrm{TCA}(\mathrm{Ser})$ & $(f \Delta) \backslash \wedge$ \\
\hline L161L & AAG(Lys ) >AAA(Lys) & $(\Gamma / \Delta))$ \\
\hline H183H & CAT(His ) $>$ CAC(His) & $(T V) 11$ \\
\hline
\end{tabular}

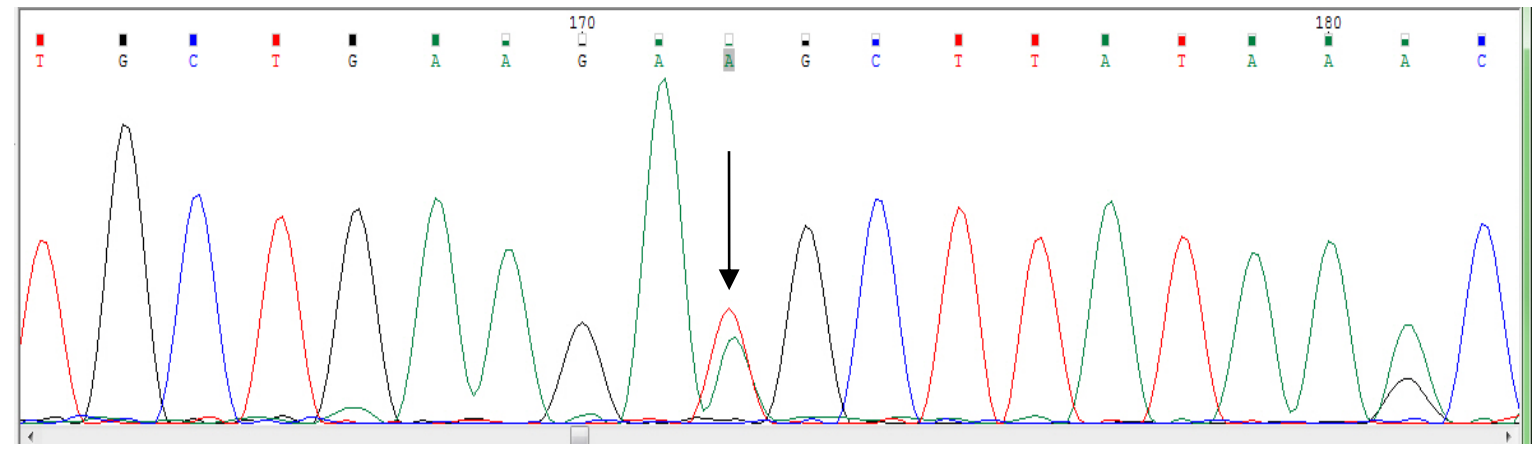

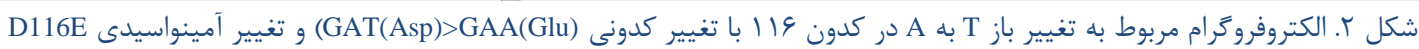




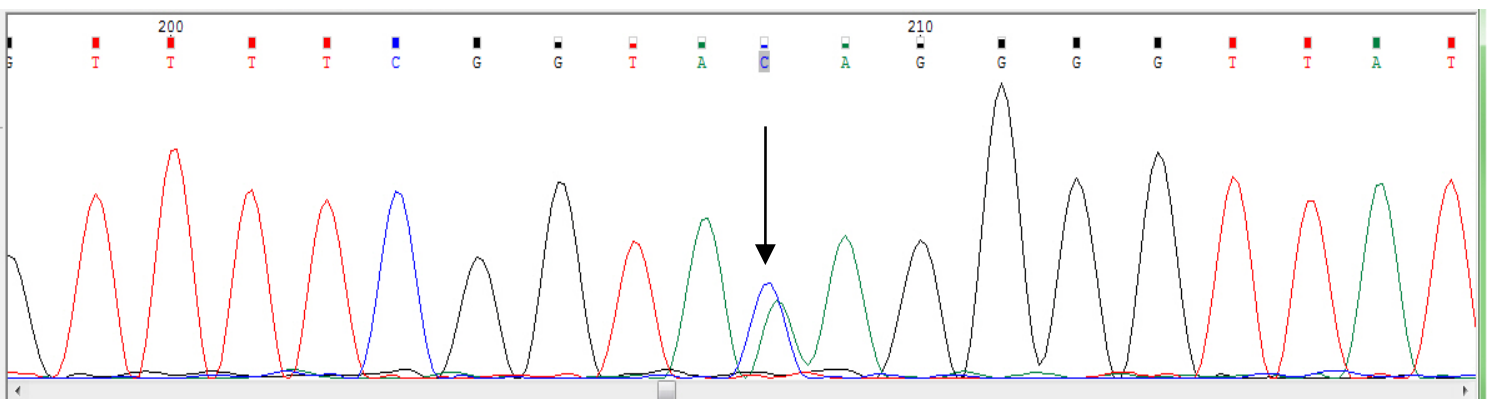

شكل r. الكتروفروكرام مربوط به تغيير باز A به Cدر كدون ش ا با تغيير كدونى (AAA(Lys )>ACA(Thr) و تغيير آمينواسيدى K128T

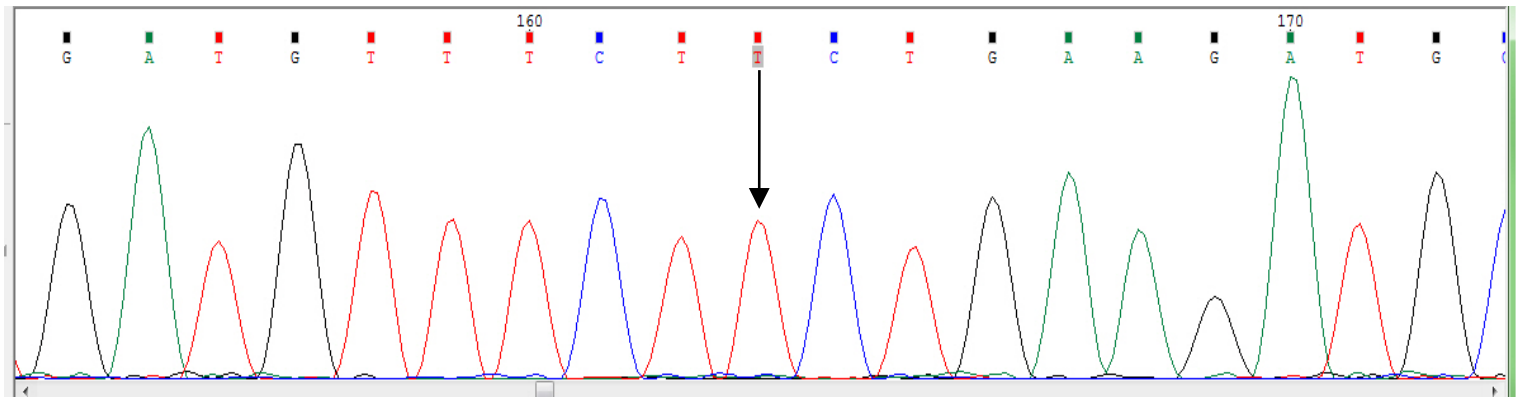

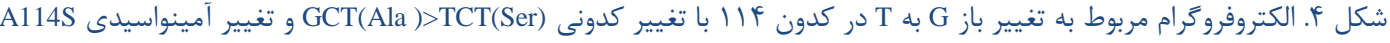

Omran

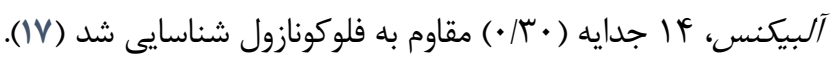
در مطالعُ Mohammadi-Ghalehbin و همكاران در شهر اردبيل در

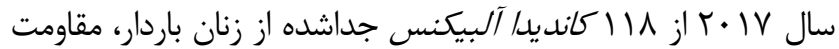

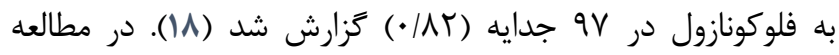
Balabandi

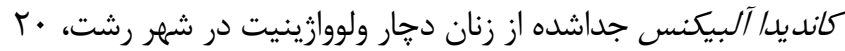
جدايه (AV/•) به فلوكونازول مقاوم بودند (^). بر اساس تحقيقات صورت گرفته موضع عفونت كانديديايى و شيوع آن در هر منطقه جغرافيايى و همجنين مصرف نادرست دارو باعث شده است نرخ متفاوتى از مقاومت به فلوكونازول در كشور و

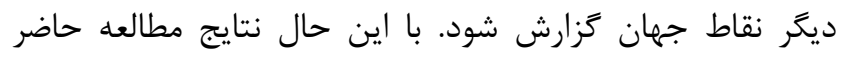

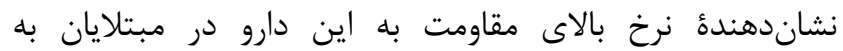

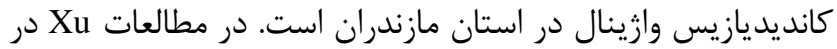

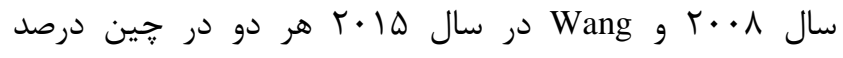
مقاومت كمتر از ·1 درصد مشاهده شد. ممكن است درصد كم

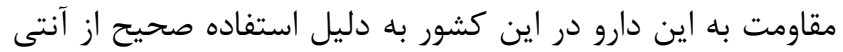

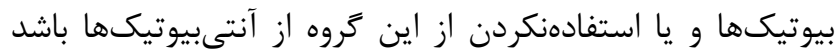

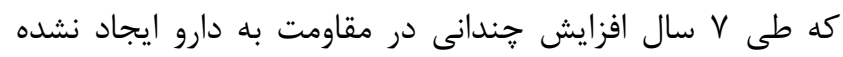

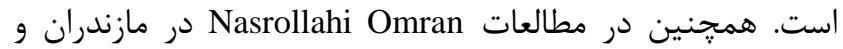
Farahbakhsh
كانديدا ياتوزن فرصتطلبى است كه قادر به ايجاد بيمارى در افراد داراى نقص ايمنى و يا ايمنى تضعيفشده است. كانديديازيس

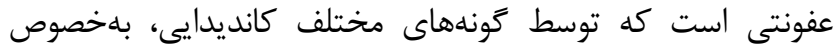

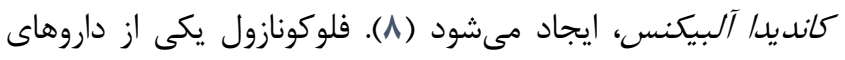

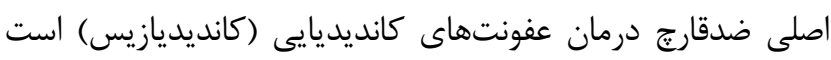

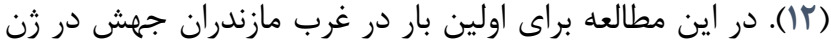
ERG11

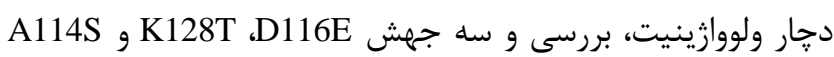
در جدايههاى مقاوم به اين دارو شناسايى شد.

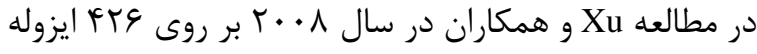

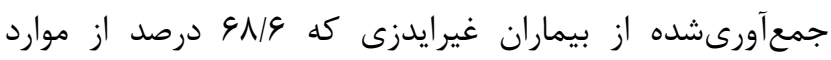

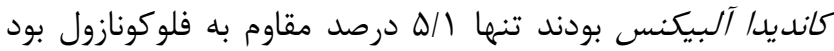

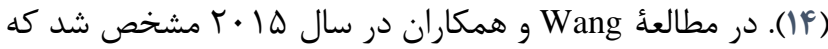

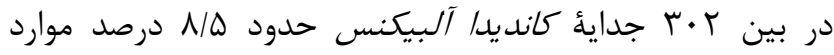
مقاوم به فلوكونازول بودند (•). در مطالعه Ungureanu و همكاران

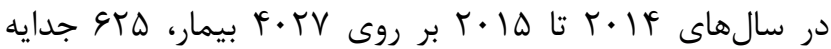

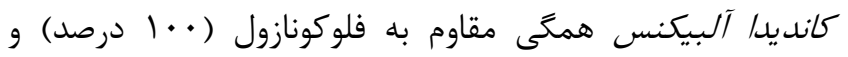

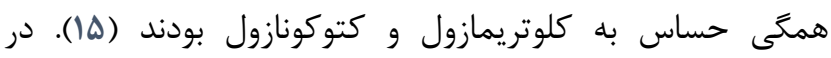

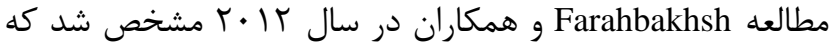
بN/V درصد جدايههاى حاصل از كانديديازيس دهانى در مبتلايان

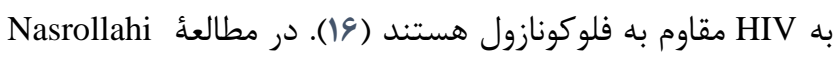


(ץ+). بر اساس مطالعات مختلف به نظر مىرسد اين جهشها به

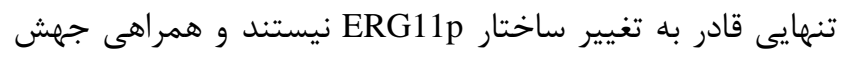

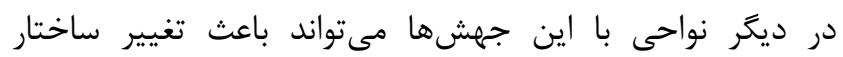

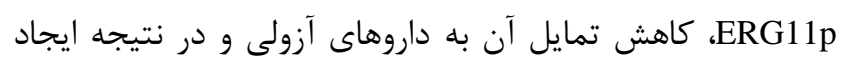

$$
\text { مقاومت به آزولها شود. }
$$

همجنين ميزان بالا MIC تعيينشده براى جدايههاى مقاوم

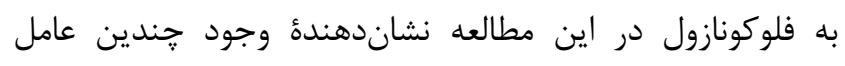

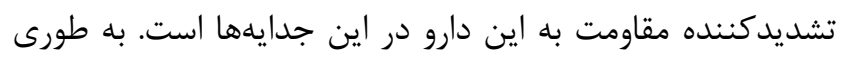

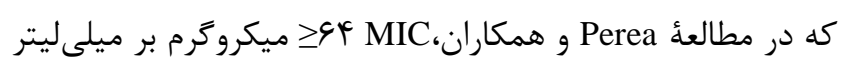

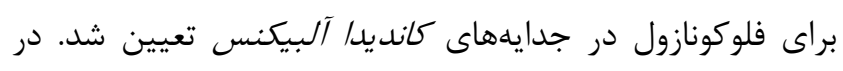

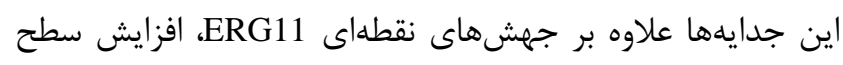

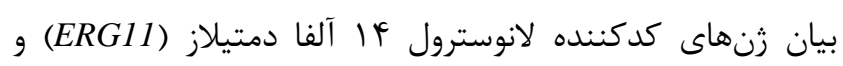

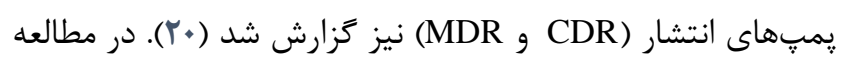

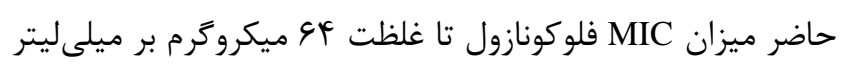

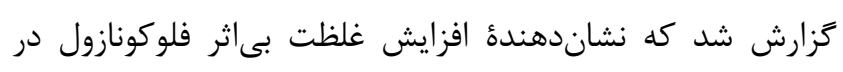

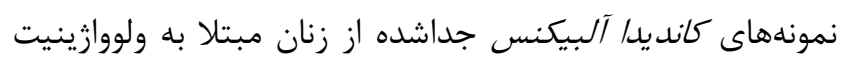

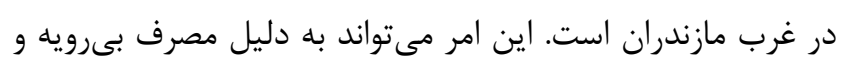

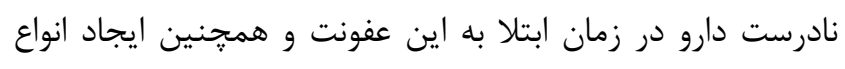

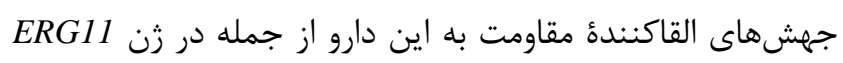

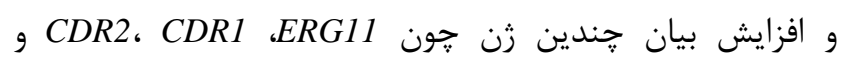
MDRI باشد كه به مطالعات بيشترى در اين زمينه نيازمند است.

$$
\text { بحث و نتيجه تيرى }
$$

در اين مطالعه نرخ بالاى مقاومت به فلوكونازول در جدايههاى

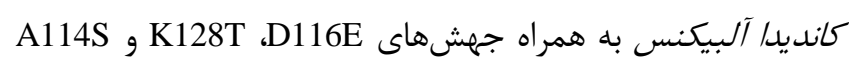

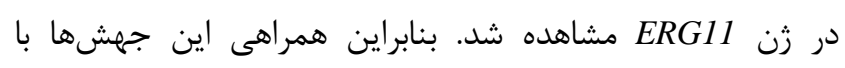

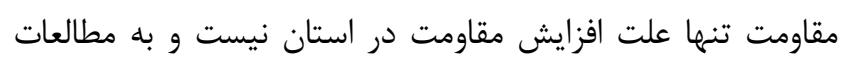

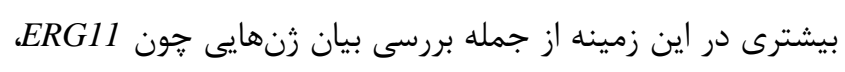
CDR2، CDR1 د MDR1 در جدايههاى مقاوم در استان نياز است.

$$
\text { سياسخزارى }
$$

اين مقاللُ تحقيقاتى حاصل پايان نامه دانشجوى كارشناسى

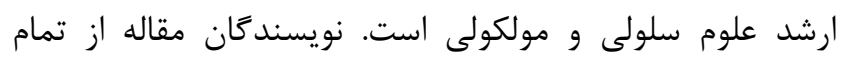

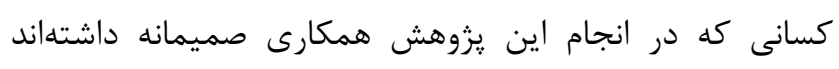
سياسگزارى مى كنند. تعارض منافع بين نويسندًان تعارض در منافع َّزارش نشده است.
فراوانى مشابهى از مقاومت به دارو مشاهده شده بود. كه در

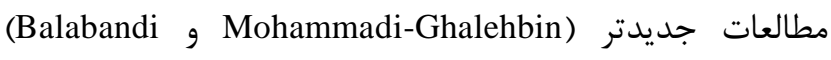
افزايش مقاومت به دارو مشاهده شد. اين امر ممكن است بـ به

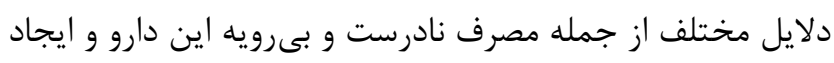

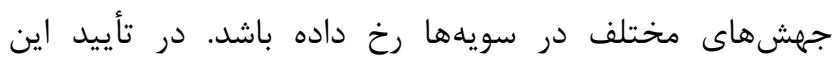

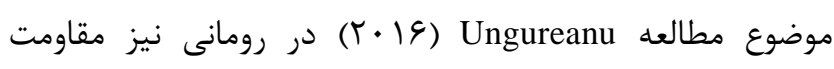

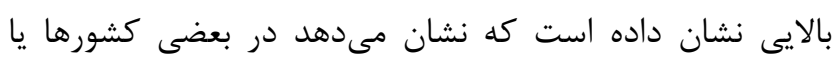

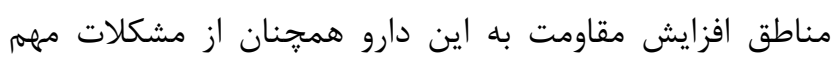

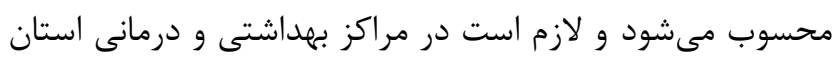

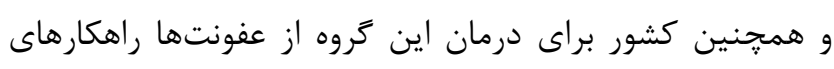
مناسبترى لحاظ شود.

در ايجاد مقاومت به آزولها مكانيسمهاى مختلفى نقش

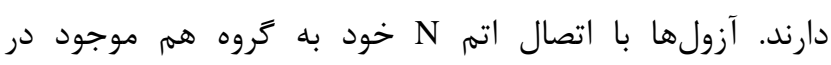

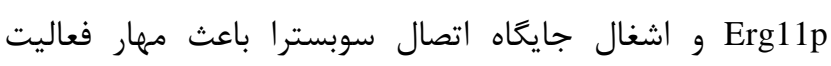

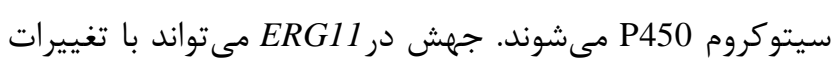

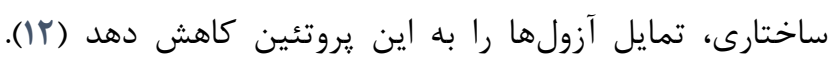

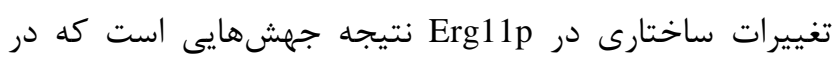

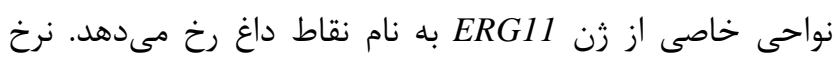

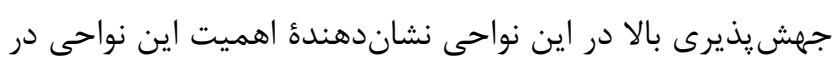

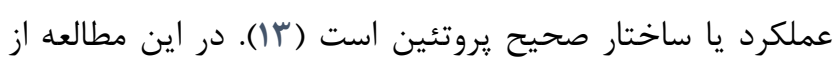

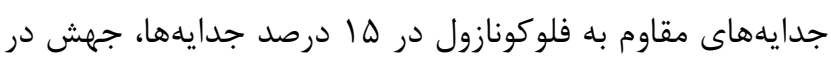
كدون 119 (D116E) در زن 1 (D) r/D درصد جدايهها جهش در كدون درصد جدايهها جهش در كدون

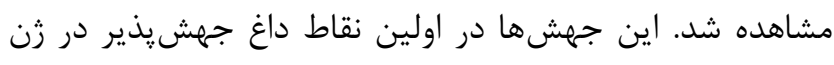
ERG11 در مطالعه Xiang و همكاران در سا • ب، از جدايههاى مقاوم و

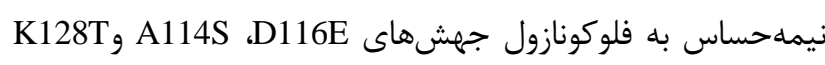
شناسايى شد كه در رابطه با مقاومت ارتباط معنادارى نداشت (II).

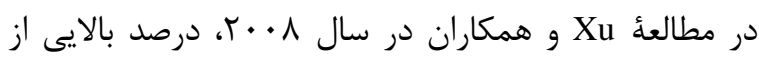

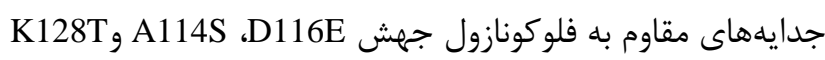

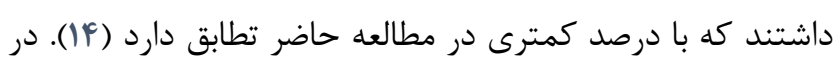

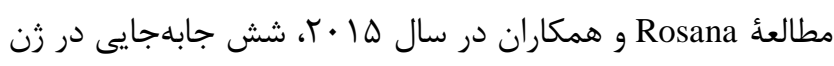

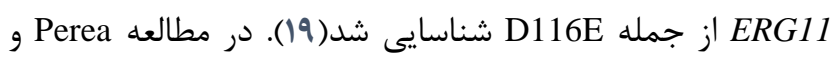

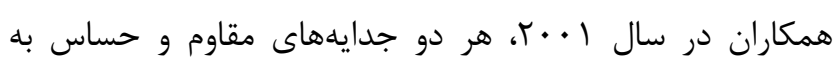

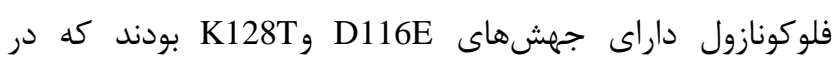
مطالعه حاضر فقط در نمونههاى مقاوم اين دو جهش ديد ديده شد 


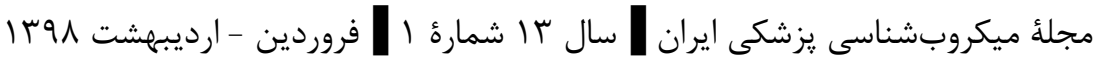

\section{References}

1. Gavanji S, Larki B. Comparative Effect of Propolis of Honey Bee and Some Herbal Extracts on Candida Albicans. Chinese Journal of Integrative Medicine. 2017; 23(3):201-7.

2. Kabir MA, Hussain MA, Ahmad Z. Candida Albicans: A Model Organism for Studying Fungal Pathogens. ISRN Microbiology. 2012; 2012:538694.

3. Pam VK, Akpan JU, Oduyebo OO, Nwaokorie FO, Fowora MA, Oladele RO, et al. Fluconazole Susceptibility and Erg11 Gene Expression in Vaginal Candida Species Isolated From Lagos Nigeria. International Journal of Molecular Epidemiology and Genetics. 2012;3(1):84-90.

4. Reiss E, Tanaka K, Bruker G, Chazalet V, Coleman D, Debeaupuis JP, et al. Molecular Diagnosis and Epidemiology of Fungal Infections. Medical Mycology. 1998; 36(Suppl 1):249-57.

5. Sanglard D, Ischer F, Parkinson T, Falconer D, Bille J. Candida Albicans Mutations in the Ergosterol Biosynthetic Pathway and Resistance to Several Antifungal Agents. Antimicrobial Agents and Chemotherapy. 2003; 47(8):2404-12.

6. Cernicka J, Subik J. Resistance Mechanisms in Fluconazole-Resistant Candida Albicans Isolates From Vaginal Candidiasis. International Journal of Antimicrobial Agents. 2006; 27(5):403-8.

7. Flowers SA, Colon B, Whaley SG, Schuler MA, Rogers PD. Contribution of Clinically Derived Mutations in Erg11 to Azole Resistance in Candida Albicans. Antimicrobial Agents and Chemotherapy. 2015; 59(1):450-60.

8. Balabandi S, Khazaei -Koohpar Z, Ranji N. Correlation Between Erg11 Gene Mutations and Fluconazole Resistance in Candida Albicans Strains Isolates Isolated in From Rasht in 2015-2016 Years. Arak Medical University Journal. 2017; 20(7):13-22.

9. White TC, Holleman S, Dy F, Mirels LF, Stevens DA. Resistance Mechanisms in Clinical Isolates of Candida Albicans. Antimicrobial Agents and Chemotherapy. 2002; 46(6):1704-13.

10. Wang B, Huang LH, Zhao JX, Wei M, Fang H, Wang DY, et al. ERG11 Mutations Associated With Azole Resistance in Candida Albicans Isolates From Vulvovaginal Candidosis Patients. Asian Pacific Journal of Tropical Biomedicine. 2015; 5(11):909-14.

11. Xiang MJ, Liu JY, Ni PH, Wang S, Shi C, Wei B, et al. Erg11 Mutations Associated With Azole Resistance in Clinical Isolates of Candida Albicans. FEMS Yeast Research. 2013; 13(4):386-93.

12. Manastir L, Ergon MC, Yucesoy M. Investigation of Mutations in Erg11 Gene of Fluconazole Resistant
Candida Albicans Isolates From Turkish Hospitals. Mycoses. 2011; 54(2):99-104.

13. Debnath S, Addya S. Structural Basis for Heterogeneous Phenotype of ERG11 Dependent Azole Resistance in C.Albicans Clinical Isolates. SpringerPlus. 2014; 3:660.

14. Xu Y, Chen L, Li C. Susceptibility of Clinical Isolates of Candida Species to Fluconazole and Detection of Candida Albicans ERG11 Mutations. The Journal of Antimicrobial Chemotherapy. 2008; 61(4):798-804.

15. Ungureanu A, Gaman AE, Turculeanu A, Mitroi M, Drocas AI, Dobritoiu $M$, et al. Incidence and Antifungal Susceptibility of Candida Albicans Infections. Current Health Sciences Journal. 2016; 42(2):164-8.

16. Farahbakhsh E, Yadegari MH, Rajabi Bazl M, Taghizadeh Armaki M, Katiraee F. Identification of Fluconazole Resistance Gene Erg11 in Clinical Candida Albicans Samples Isolated From Hiv-Infected Patients by Reverse Polymerase Chain Reaction (RTPCR). Daneshvar. 2012; 19(96):19-28.

17. Nasrollahi Omran A, Nazemi A, Kihanian S, Aryana N. Lipase Gene Expression of Resistant and Sensitive Candida Albicans to Fluconazole Isolated From Patients Suffering From Oral Candidiasis and Vaginal Candidiasis. Medical Laboratory Journal. 2015; 8(5):9096.

18. Mohammadi-Ghalehbin B, Javanpour Heravi H, Arzanlou M, Sarvi M. Prevalence and Antibiotic Resistance Pattern of Candida spp; Isolated From Pregnant Women Referred to Health Centers in Ardabil, Iran. Journal of Ardabil University of Medical Sciences. 2017; 16(4):409-421.

19. Rosana Y, Yasmon A, Lestari DC. Overexpression and Mutation as a Genetic Mechanism of Fluconazole Resistance in Candida Albicans Isolated From Human Immunodeficiency Virus Patients in Indonesia. Journal of Medical Microbiology. 2015; 64(9):1046-1052.

20. Perea S, Lopez-Ribot JL, Kirkpatrick WR, McAtee RK, Santillan RA, Martinez M, et al. Prevalence of Molecular Mechanisms of Resistance to Azole Antifungal Agents in Candida Albicans Strains Displaying High-Level Fluconazole Resistance Isolated From Human Immunodeficiency VirusInfected Patients. Antimicrobial Agents and Chemotherapy. 2001; 45(10):2676-2684. 